\title{
Injury in the Americas: the relative burden and challenge
}

\author{
Laura Fraade-Blanar, ${ }^{1}$ Alberto Concha-Eastman, ${ }^{2}$ \\ and Timothy Baker ${ }^{1}$
}

Suggested citation Fraade-Blanar L, Concha-Eastman A, Baker T. Injury in the Americas: the relative burden and challenge. Rev Panam Salud Publica. 2007;22(4):254-9.

\begin{abstract}
Objectives. To present evidence to support a higher priority for injury prevention in initiatives, research, and budget allocations.

Methods. Recent data (2000) for deaths from injury, infectious disease, heart disease, and cancer from 11 countries in the Region of the Americas were analyzed. Analyses focused on: first, Potentially Productive Years of Life Lost (PPYLL, discounted) from deaths occurring from 0-64 years of age; second, Years of Potential Life Lost (YPLL) from 1-64 years; and third, Years Lived with Disability (YLD). The burdens of injury and infectious disease were compared to the Pan American Health Organization (PAHO) budget allocations for these areas.

Results. There is a clear-cut disparity between funds allocated and the magnitude of injury burden as compared to the burden of infectious disease.

Conclusions. In making decisions on budgetary allocations, the Member States of PAHO must consider the potential impact of injury research and control on the health of their populations.
\end{abstract}

Key words Accident prevention, wounds and injuries, budget, Pan American Health Organization.

The Pan American Health Organization (PAHO) pioneered efforts to recognize and measure the burden of injury on its Member States. As early as 1984, in its quadrennial publication Health Conditions in the Americas (1), PAHO identified unintentional injury as the leading cause of lost years of life

\footnotetext{
${ }^{1}$ Johns Hopkins Bloomberg School of Public Health, Department of International Health, Baltimore, Maryland, United States of America (USA). Send correspondence to: Laura Fraade-Blanar, 2100 Connecticut Avenue, N.W., Washington, DC, 2008, USA; telephone: +01 410-905-7763; e-mail: lfraade@ jhsph.edu.

2 Pan American Health Organization, Risk Assessment Unit, Sustainable Development and Environmental Health Area, Washington, DC, USA.
}

in two-thirds of countries in the Americas. Homicide and suicide were also among the top five causes of lost years of life in many countries. The report measured the Years of Potential Life Lost (YPLL), a technique similar to that used by the United States Centers for Disease Control and Prevention (CDC) as a fundamental measure of premature death $(1,2)$.

The purpose of this study is to contrast the burden of injury with the burden of infectious disease and chronic disease, including malignant neoplasm and diseases of the circulatory system, in 2000, and to compare these burdens with PAHO budget allocations for injuries and infectious disease. Three measures of disease burden were analyzed: first, Years of Potential Life Lost (YPLL), following PAHO's original measures from Health in Conditions in the Americas (1); second, Potentially Productive Years of Life Lost (PPYLL), to better inform policy decisions on the economic drivers that influence health priorities; and third, Years Lived with Disability (YLD), as a morbidity measure. Intentional injuries were separated from unintentional injuries. Finally, the magnitude of the burden of injury and 
that of infectious disease were compared to PAHO budgetary allocations for each.

\section{The pattern of injuries in the Americas}

Road traffic deaths outweigh other unintentional injuries. In 2000, the road traffic mortality rate was 20.8 per 100000 in the Americas (3). Pedestrians, bicyclists, and motorcyclists sustain more frequent and severe injuries than vehicle occupants (4). Vehicles in poor condition or lacking safety features, excessive speed, poor driver knowledge and behavior, social norms, intoxicating substances and alcohol, unsafe roads, and poor EMS systems all contribute (4).

Within the intentional injury category, homicide predominates, with especially high rates in Brazil, Colombia, El Salvador, Guatemala, Mexico, and Puerto Rico (4). The Region of the Americas has averaged 19.3 homicides per 100000 per year (5); a regional rate among the highest in the world. Injury mortality is concentrated in the age group 15-34 years of age (6).

A person's disability or death results in lost productivity, placing his or her family in a precarious economic position. In developing countries, injury losses are estimated to represent $3 \%-5 \%$ of the gross national product (GNP) (7).

\section{MATERIALS AND METHODS}

\section{Data sources}

PAHO currently has 35 Member States. This study's inclusion criteria were (1) a minimum population of 10 million and (2) available, comprehensive population and mortality data. The 11 countries included comprise $88 \%$ of the total population of the Region of the Americas. These 11 represent a range of mortality strata defined by the World Health Organization (WHO), namely, (1) Mortality Stratum A (very low child and adult mortality): Canada, the United States, and Cuba; (2) Mortality Stratum B (low child and adult mortality): Argentina, Brazil, Chile, Colombia, Mexico, and Venezuela; (3) Mortality Stratum C (low child and high adult mortality): no country in the Americas; and Mortality Stratum D (high child and adult mortality): Ecuador and Guatemala (8).

The most recently available mortality and population data (year 2000) for all 11 countries were obtained from the WHO Statistical Information System (WHOSIS), specifically from Table 1: Numbers and Rates of Registered Deaths (9). YLD data from 2002 was provided by WHOSIS as well (10). The data were imported into Microsoft Office Excel (Microsoft Corp., Redmond, Washington, USA).

The International Statistical Classification of Diseases and Related Health Problems, 10th Revision (ICD-10) codes for infectious diseases used were A00-B99, plus I00-I02 (acute rheumatic fever) and J12-J18 (pneumonia). Acute rheumatic fever and pneumonia are infectious diseases that are not included in the ICD-10 infectious disease category. ICD-10 codes used for injuries were V01-X59, Y40-Y86, Y88 (unintentional injury), X60-X84 (suicide), X85-Y09 (homicide), and Y10-Y36, Y87, and Y89 (other external causes). We also measured the burden of disease for two chronic disease groups: malignant neoplasm, C00-C97; and diseases of the circulatory system, I00-I99 (9).

Budget allocations for 2004-2005 and 2006-2007 and country goals for 2006-2007 were obtained from the PAHO biennial program budget proposal, as found on the organization's website $(11,12)$.

\section{Analysis}

YPLL among those 1-64 years of age (YPLL) and PPYLL among those 0-64 years of age (PPYLL) and were used to analyze mortality burden. YLD assessed the morbidity burden.

YPLL measures the quantity of years of life lost prematurely at the time of death. This measurement emphasizes the PAHO mission to lengthen the lives of Americans. The estimates are determined by multiplying the mortality in each age group (1-4 years, 5-14 years, 15-24 years, 25-34 years, 35-44 years, $45-54$ years, and 55-64 years) by the difference between 64 years and the midpoint of each age group and then summing all age groups (1). Deaths under 1 year of age were excluded following the PAHO methodology for mortality data and YPLL. For more information, refer to the National Center for Health Statistics at the CDC website (2), or the 1984 Health Conditions in the Americas (1).

PPYLL quantifies burden based on the relative economic value of each age group, measuring the future productive working years as beginning at age 15 and ending at age 64. In methodology, the calculations are similar to that of YPLL with the additional step of discounting.

For details on calculating YLD, refer to the Global Burden of Disease (13).

YLD and PPYLL use discounting, which recognizes that "years in the future are worth less then years in the present" (14). Therefore, discounting places greatest emphasis on the death of a person currently contributing to the economy, precisely:

The PPYLL method applies a 3\% discount rate, compounded for years of life in the future lost to premature death. The World Bank and World Health Organization also use a 3\% discount rate. The method calculates future years lost from death in each 10 year age group from the midpoint of that period . . . for example, deaths in the 15-24 year age group would result in an average of 45 lost years of productive work. Discounted by a compounded annual $3 \%$, this would be about 25 years lost ... The loss of potentially productive years of life ... is discounted back to the midpoint of their age group (14).

This discounting is then combined with the mortality rates to yield a burden estimate. For more information, refer to The Global Burden of Disease (13). 


\section{RESULTS}

In the 11 countries examined, in 2000 the cumulative PPYLL from injuries exceeded the burden of infectious diseases, diseases of the circulatory system, or malignant neoplasms (Figure 1). Analyses of individual countries follow the same pattern, except in Ecuador and Guatemala where the infectious diseases burden was greater, and in Canada where malignant neoplasm was greater.

In the Americas as a whole, the burden of injuries exceeded that of infectious diseases, malignant neoplasms, and diseases of the circulatory system in YPLL in 2000 (Figure 2). In 10 of the 11 individual countries analyzed this held true. In Guatemala, the exception, the burden of infectious diseases was larger.

Morbidity is expressed by YLD from 2002 (Figure 3) and is considerably higher for injury than for infectious diseases, diseases of the circulatory system, or malignant neoplasms.

Unintentional injuries exceeded external injuries of undetermined intent and intentional injuries in YPLL and PPYLL in all but Brazil, Colombia, Guatemala, and Venezuela, where intentional injuries created a greater burden (Figure 4).

Within unintentional injuries, road traffic injury burden leads all other causes. In countries with greater intentional injury burden, homicide is generally greater than suicide.

According to the PAHO biennial program budget proposal, injuries, violence, and disabilities received US\$ 961400 in the 2004-2005 regular budget (WHO funds and Member States contributions). In the 2006-2007 budget, injuries, violence, and disability received US\$ 2055600 (Figure 5) (11). This increase came mainly from outside sources including the CDC, the United States Agency for International Development (USAID), and the Deutsche Gesellschaft für Technische Zusammenarbeit (GTZ). These funds are disseminated at the local, national, and regional levels, and cover a wide swath of programs, campaigns, and initiatives. Within country goals and
FIGURE 1. Potentially Productive Years of Life Lost (PPYLL) 0-64 for 11 PAHO Member States, 2000

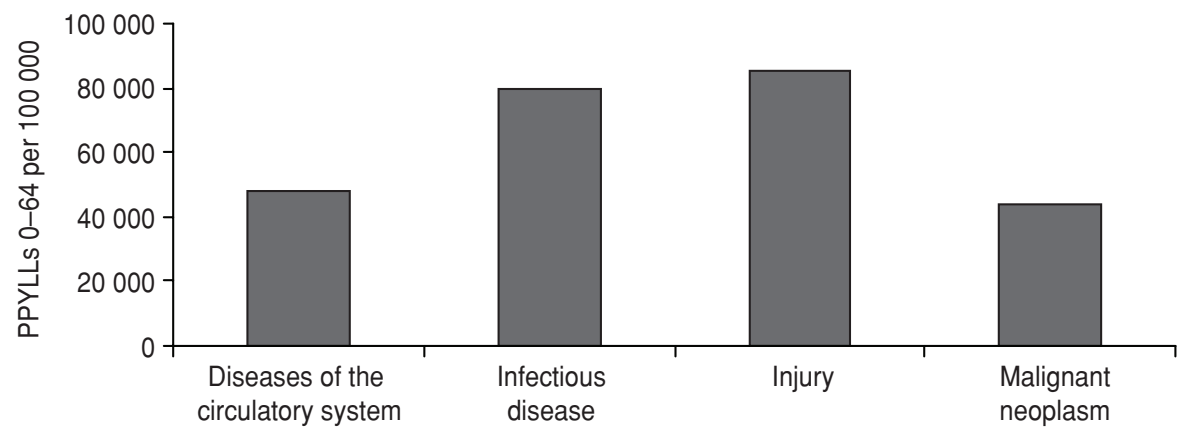

FIGURE 2. Years of Potential Life Lost (YPLL) 1-64 for 11 PAHO Member States, 2000

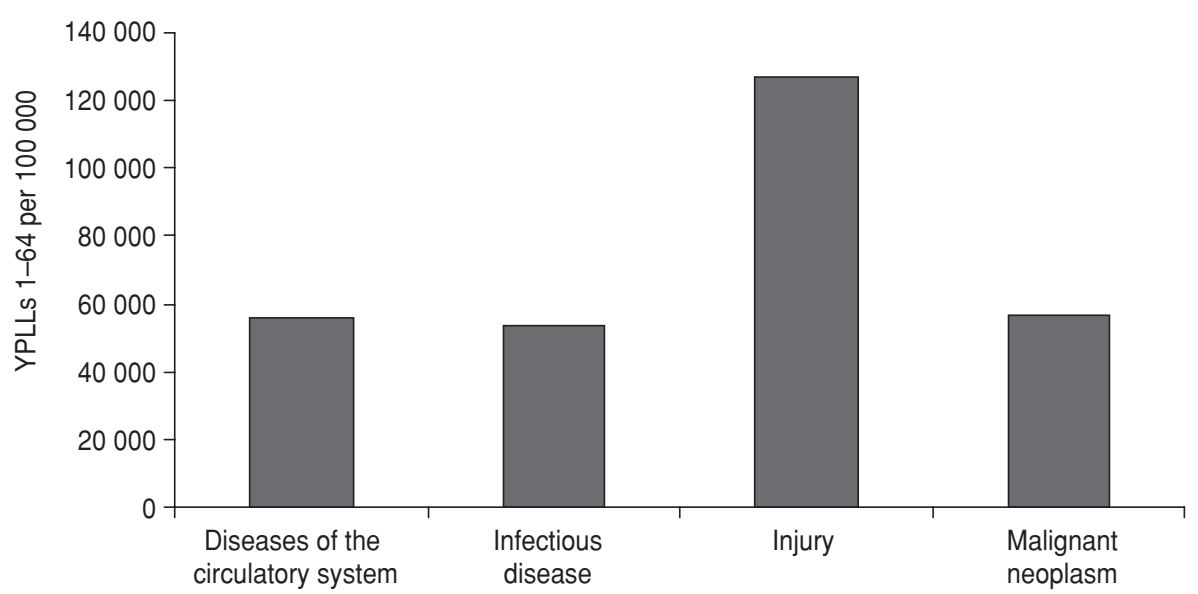

FIGURE 3. Years Lived with Disability (YLD) within the Americas, 2002

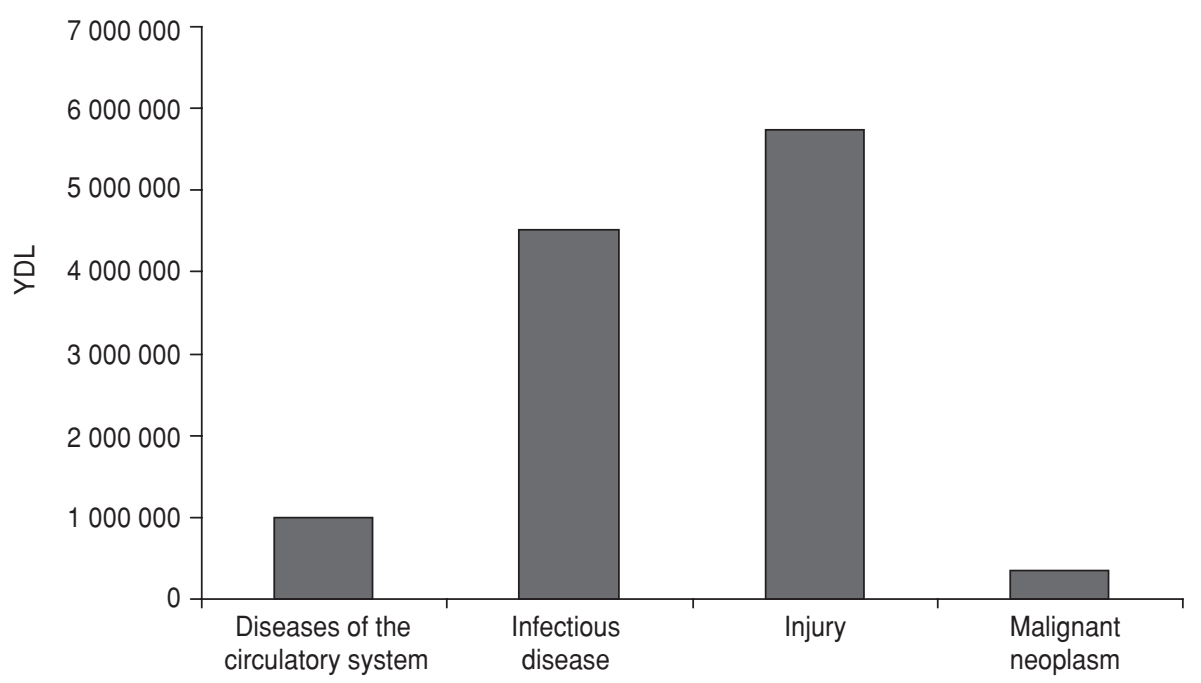


FIGURE 4. Years of Potential Life Lost (YPLL) 1-64 for injury for 11 PAHO Member States, 2000

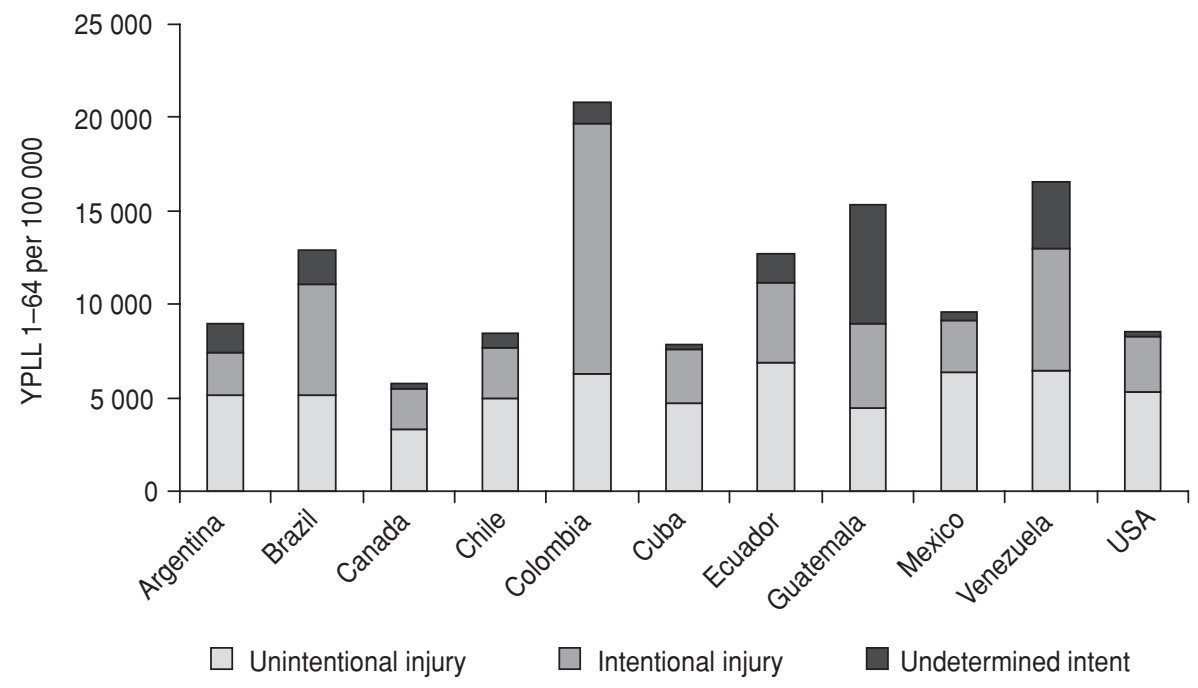

programs, 24 of the Member States reference injury. Those that do include injuries state general goals, such as "(develop) capacity to design and implement evidence-based plans and programs for violence and injury prevention, control, and monitoring" (12) or goals oriented toward specific issues within the country. Of those with specific goals, the majority reference intentional injury over unintentional road traffic injuries (12).

The total budgetary allocation for infectious diseases in 2006-2007 was US\$ 107.2 million (Figure 5). Seventysix percent comes from voluntary contributions, with the remainder from the regular budget. The infectious disease budget includes all funds for

FIGURE 5. PAHO budgetary allocations for 2006-2007

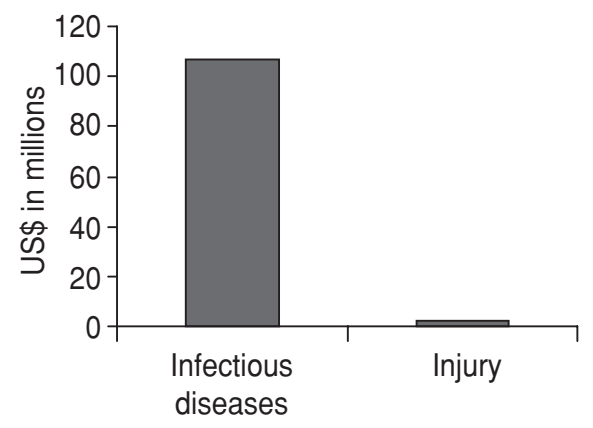

communicable disease prevention and control, epidemic alert systems, research, and targeted diseases initiatives, such as malaria, tuberculosis, and HIV / AIDS. Infectious diseases received roughly 50 times more funding than injury, violence, and disability (Figure 5) (11).

\section{CONCLUSIONS}

The extent of the burden of injury in the Region of the Americas is clear from the analysis of PAHO data. Every year approximately 133783 people die as a result of road traffic injuries (15) and 159000 are murdered (5). At the national, regional, and international level, the response has not been proportional to the problem.

While the importance of infectious and chronic disease is indisputable, injuries receive inadequate public attention. Most national governments recognize the burden of injuries; however, this recognition has rarely resulted in formal plans or tangible change (16). Social norms defined by fatalism and the inevitability of injury are often cited as barriers $(16,17)$. The lack of injury research, most notably in the area of interventions (16), is also a major barrier to combating the toll of injury.
What are the reasons for the lack of support for and commitment to injury control?

- Entrenched, erroneous beliefs that injuries are "accidents," and little or nothing can be done to prevent them.

- A critical mass of committed, injury control professionals has not been reached.

- Few partnerships for funding the implementation of injury control measures exist in Member States.

- There is a paucity of data on the cost-effectiveness of various injury interventions.

- Successful injury control programs that could serve as models for other nations are not well disseminated throughout the international community.

What are some of the steps that can be taken to combat the terrible burden of injuries in the Americas?

First, Member States must be informed of the magnitude of the injury problem, both in absolute numbers and relative to other health problems, and must come to understand the modern concepts of injury control.

Second, it is necessary to convince Member States that injuries are preventable and much can be done to decrease the burden. Currently there are efforts to this end; however, policy change requires continued work and evidence.

Third, existing and new public health professionals and new personnel should be trained in proven injury control; developing a cadre of specialists. These professionals could (1) advocate for injury control, (2) sponsor new research, (3) continue existing research within the field, and (4) inform and coordinate activities at the country, state, and local levels.

Fourth, new alliances must be forged between intergovernmental organizations such as PAHO, nongovernmental organizations, and national governments. A century ago, medical professionals in public health forged alliances with sanitary engineers to improve the vital services, such as 
water supply, malaria control, and safe sewerage. Today, health professionals should build alliances with civil engineers who plan, design, and build roads in the Americas, and with local law enforcement agencies, automotive engineers, and above all, with funding agencies such as the World Bank and the Inter-American Development Bank.

Fifth, the cost-effectiveness of injury interventions should be researched further. While there is a paucity of data on the subject, existing studies suggest interventions such as enforced speed control and helmet usage, seat belts, and improved emergency medical systems can have large impacts on health for a relatively small price, especially when compared with other health care interventions. Dr. John Graham's landmark review of the cost-effectiveness of a variety of interventions is instructive (Table 1) (18). More research is needed; the least cost-effective option is to fail to implement injury interventions.

Sixth, low- and middle-income countries can adapt lessons learned in high-income countries. A good example is the establishment of traffic safety regulations in Brazil where the death rate from motor vehicle injuries was lowered $20 \%$ in car occupants and $9 \%$ in motorcycle-related injuries shortly after enforcement of legislation (19). San Jose, Costa Rica, implemented

TABLE 1. Life-saving interventions and cost

\begin{tabular}{|c|c|c|}
\hline $\begin{array}{l}\text { Intervention } \\
\text { category }\end{array}$ & Intervention & $\begin{array}{c}\text { Cost per } \\
\text { life-year } \\
\text { saved (US\$) }\end{array}$ \\
\hline \multirow[t]{4}{*}{ Injury } & $\begin{array}{l}\text { Mandatory motorcycle helmet laws } \\
\text { (rather than state determined policies) }\end{array}$ & 2000 \\
\hline & Advanced life support and paramedic equipped vehicle & 5400 \\
\hline & Airbag/manual belts (rather than manual belts only) in cars & 6700 \\
\hline & smoke detectors in houses & 8100 \\
\hline \multirow[t]{2}{*}{ Environmental } & Chlorination, filtration, and sedimentation of drinking water & 4200 \\
\hline & ban asbestos in roofing materials & 550000 \\
\hline \multirow[t]{2}{*}{ Chronic disease } & Low cholesterol diet for men age 60 with $180 \mathrm{mg} / \mathrm{dl}$ & 12000 \\
\hline & annual cervical cancer screening starting at age 20 & 82000 \\
\hline \multirow[t]{4}{*}{ Infectious disease } & Influenza vaccine for people age 5+ & 1300 \\
\hline & Screen blood for HIV & 14000 \\
\hline & $\begin{array}{l}\text { Isoniazid chemotherapy for low risk white male tuberculin } \\
55 \text { reactors aged }\end{array}$ & 17000 \\
\hline & AZT for AIDS patients & 26000 \\
\hline
\end{tabular}

Source: Based on a literature review of available data (18).

community policing programs, leading to a decline in crime and an increase in perceived personal safety (5). Cali and Bogota, Colombia, banned carrying firearms during certain time periods known to have high homicide rates, temporarily lowering the incidence of homicide (5). Bogota also introduced a mass transit program for vulnerable road users as a method of decreasing risk of motor vehicle injury (15).
Seventh, and most important, is to provide adequate funding for injury prevention, funding that is in proportion to the size of the problem and the potential for its reduction. PAHO and its Member States are in a unique position to take a leadership role within the above initiatives. Over the next decade, we must find affordable and effective ways to lower the toll of injuries in the Americas.

\section{REFERENCES}

1. Pan American Health Organization. Health conditions in the Americas. 1986 ed. Washington, D.C.: PAHO; 1986.

2. Centers for Disease Control and Prevention. Years of potential life lost [Internet site]. Centers for Disease Control and Prevention. Available from http://www.cdc.gov/nchs/ datawh/nchsdefs/yearsofpotentiallifelost. htm. Accessed 1 April 2006.

3. Pan American Health Organization. Deaths from motor vehicle traffic accidents in selected countries of the Americas, 1985-2001. Epidemiol Bull. 2004 Mar;25(1):2-54.

4. Pan American Health Organization. Health conditions in the Americas. 2007 ed. Washington, D.C.: PAHO; 2007.

5. World Health Organization. World report on violence and health. Geneva: World Health Organization, 2002.

6. Segui-Gomez M, MacKenzie EJ. Measuring the public health impact of injuries. Epidemiol Rev. 2003; 25:3-19.
7. Global Road Safety. The coming plague of road traffic injuries: a preventable burden for rich and poor countries [Internet site]. Global Road Safety. Available from http://www. globalroadsafety.org/. Accessed 1 April 2006.

8. World Health Organization. List of Member States by WHO region and mortality stratum [Internet site]. WHO. Available from http:// www.who.int/whr/2003/en/member_states 182-184_en.pdf. Accessed 14 October 2007.

9. World Health Organization. Table 1: registered deaths [Internet site]. World Health Organization. Available from http://www3. who.int $/$ whosis $/$ mort $/$ table1.cfm?path= whosis,mort,mort_table1\&language $=$ english . Accessed 1 April 2006.

10. World Health Organization. Years lost due to disability [Internet site]. World Health Organization. Available from http://www.who. int/healthinfo/bodgbd2002revised/en/index. html. Accessed 14 October 2007.
11. Pan American Health Organization. Biennial program budget proposal for 2006-2007: areas of work [Internet site]. Pan American Health Organization. Available from http:// www.paho.org/english/gov/ce/bpb0607AoW-e.pdf. Accessed 1 April 2006.

12. Pan American Health Organization. Biennial program budget proposal for 2006-2007: countries [Internet site]. Pan American Health Organization. Available from http://www.paho.org/english/gov/ce/ bpb0607-countries-e.pdf. Accessed 1 April 2006.

13. Lopez AD, Murray CJL. The global burden of disease. Geneva: World Health Organization, 1999.

14. Zhou Y, Baker TD, Rao K, Li G. Productivity losses from injury in China. Inj Prev. 2003 Jun; 9(2):124-7.

15. World Health Organization. World report on road traffic injury prevention. Geneva: WHO, 2004 
16. Blank D. Injury control in South America: the art and science of disentanglement [editorial]. Inj Prev. 2004 Dec;10(6):321-4.

17. Vasconcellos EA. Urban development and traffic accidents in Brazil. Accid Anal Prev. 1999 Jul;31(4):319-28.
18. Tengs TO, Adams ME, Pliskin JS, Safran DG, Siegel JE, Weinstein MC, Graham JD. Fivehundred life-saving interventions and their cost-effectiveness. Risk Anal. 1995 Jun;15(3): 369-90.

19. Liberatti CL, Andrade SM, Soares DA. The new Brazilian traffic code and some charac- teristics of victims in southern Brazil. Inj Prev. 2001 Sep;7(3):190-3

Manuscript received 7 July 2006. Revised version accepted for publication 18 September 2007.

RESUMEN Objetivos. Presentar evidencias que respalden que la prevención de los traumatismos debe ser una prioridad para las iniciativas y la investigación en la Región.

Métodos. Se analizaron datos recientes (2000) de las muertes por traumatismos, en-

Los traumatismos en las Américas: carga relativa y desafíos

Palabras clave fermedades infecciosas, enfermedades cardíacas y cáncer en 11 países de la Región de las Américas. El análisis se centró en: a) años de vida productiva potencial perdidos (descontados) por las muertes ocurridas entre 0 y 64 años de edad; $b$ ) años de vida potencial perdidos por las muertes ocurridas entre 1 y 64 años de edad; y c) los componentes principales de las causas externas de muerte. Se compararon las cargas por traumatismos y por enfermedades infecciosas con los presupuestos asignados por la Organización Panamericana de la Salud (OPS) para las áreas correspondientes.

Resultados. Se observó una clara discrepancia entre los fondos asignados y la magnitud de la carga por traumatismos, en comparación con la carga por enfermedades infecciosas.

Conclusiones. Al decidir las asignaciones presupuestarias, los Países Miembros de la OPS deben tomar en cuenta el impacto potencial de las investigaciones sobre los traumatismos y su control en la salud de sus poblaciones.

Prevención de accidentes, heridas y traumatismos, presupuestos, Organización Panamericana de la Salud.

\section{9. ${ }^{\text {a }}$ Conferencia Mundial sobre Prevención de Lesiones y Promoción de la Seguridad (9th World Conference on Injury Prevention and Safety Promotion)}

Fecha: 15 al 18 de marzo

Lugar: Mérida, Yucatán, México

Esta Conferencia dará atención especial a los procesos de globalización y sus implicaciones para las lesiones y la violencia. También se enfatizarán los modelos globales en transiciones tecnológicas y epidemiológicas, y la colaboración internacional como una estrategia fundamental para el diseño y la promoción de políticas para la prevención de lesiones y la promoción de la seguridad.

\section{Temas}

Seguridad en el transporte $\bullet$ Violencia $\bullet$ Lesiones autoinfligidas $\bullet$ Seguridad en el trabajo $\bullet$ Lesiones no intencionales • Servicios de urgencia, atención médica y rehabilitación del trauma • Promoción de recursos humanos y evaluación de programas de prevención - Definición de políticas públicas para la prevención de lesiones y promoción de ambientes seguros • Adelantos en investigación y vigilancia de lesiones accidentales y violencia.

\section{Información}

Correo electrónico: safety2008@insp.mx

Internet: http://www.insp.mx/safety2008/ 